\title{
Association between the Ovine MHC-DRB1 Gene and its Resistance to Gastrointestinal Parasites in Deccani Sheep Raised in Hot Semi-arid Ecosystem of India
}

A.Y. Devkatte, P.V. Jadhav, Rajiv Kumar, V.B. Dongre,

Priya Sharma1', N.Z. Gaikwad, B.S. Khillare

10.18805/IJAR.B-4781

\begin{abstract}
Backgroung: Major histocompatibility complex (MHC) is linked with the ability of sheep to resist infection by GIN as measured by feacal egg count. Present study was carried out to genotype Deccani sheep for DRB1 locus and associate it with parasitic resistance. Methods: PCR SSCP analysis for Ovar-DRB1 exon 2 and part of intron-1 was carried out under optimum conditions. Effect of genetic and nongenetic factors along with the genotype was performed using linear model of least square analysis by considering log transferred faecal egg count as a dependent variable.

Result: PCR SSCP analysis revealed presence of 14 SSCP patterns. The factors such as age, sex, farm and birth type demonstrated a non significant effect on faecal egg count however, season was observed to be significant source of variation. Further, it was observed that, genotype $\mathrm{J}$ and $\mathrm{F}$ could be possibly associated with resistance and susceptibility to parasitic infection. Thus, it was inferred that $D R B 1$ gene is may be associated with immune response to parasitic invasion and selection for genotype associated with Ovar-Mhc-DRB1 gene could improve the parasitic resistance in Deccani sheep.
\end{abstract}

Key words: Deccani, Feacal egg count, Ovar-DRB1 gene, PCR-SSCP.

\section{INTRODUCTION}

Sheep husbandry is an important and sustainable livelihood resource for people living in the arid and semi-arid regions of the world since long time. The rearing of small ruminants is very important, since they serve as a lifeline during drought years by providing income and sustenance to the farming community and grazers (Rangnekar, 2006). Sheep population of India is 74.26 million and accounts for almost 13.87 percent of the total livestock and India ranks second in the world (DAHD, 2019). Deccani sheep is drought resistant sturdy breed of Deccan plateau, particularly Maharashtra state. Gastrointestinal parasites, particularly the gastro intestinal nematodes (GIN) is one of the major constraints in sheep husbandry contributing to overall production losses for the shepherds by affecting the production performance of small ruminants (Kumar et al., 2008). Individual as well as breed wise variations to different parasitic infection resistance and susceptibility are seen in animals (Saddiqi et al., 2011).

Many researchers link the genes in the sheep major histocompatibility complex (MHC) with the ability of sheep to resist infection by GIN as measured by feacal egg count (FEC) and revealed polymorphisms in exon 2 and adjoining intron 2 of the expressed gene DRB1. The DRB1 exon 2 encodes $\beta 1$ domain, which constitutes part of the protein binding receptor $(P B R)$ or T-cell receptors of the $D R$ molecules and is likely to be related to functionality such as disease resistance/susceptibility (Paterson et al., 1998; Charon et al., 2002; Ashrafi et al., 2014 and Valilou et al., 2015). The $D R$ genes are highly polymorphic in nature and
Department of Veterinary Parasitology, College of Veterinary and Animal Sciences, Latur-413 517, Maharashtra, India.

${ }^{1}$ ICAR-Central Sheep and Wool Research Institute, Avikanagar304 501, Rajasthan, India.

Corresponding Author: P.V. Jadhav, Department of Veterinary Parasitology, College of Veterinary and Animal Sciences, Latur413 517, Maharashtra, India. Email: drprajaktavet@gmail.com

How to cite this article: Devkatte, A.Y., Jadhav, P.V., Kumar, R., Dongre, V.B., Sharma, P., Gaikwad, N.Z. and Khillare, B.S. (2022). Association between the Ovine MHC-DRB1 Gene and its Resistance to Gastrointestinal Parasites in Deccani Sheep Raised in Hot Semi-arid Ecosystem of India. Indian Journal of Animal Research. DOI: 10.18805/IJAR.B-4781.

Submitted: 22-09-2021 Accepted: 05-01-2022 Online: 22-02-2022

proteins encoded by these genes are expressed in elevated concentrations, specifically on the cell membranes of macrophages and B cells (Outteridge et al., 1996). The highly variable residues concentrated in this region are in close contact with the peptides presented in the PBR or the TCR (Brown et al., 1993). In view of this, an investigation was carried out to genotype exon 2 of DRB1 locus of OvarMhc and assesses its association with FEC in Deccani sheep.

\section{MATERIALS AND METHODS}

Blood collection, processing and PCR amplification

The present investigation includes total of 50 unrelated Deccani sheep reared at Instructional Livestock Farm 
Complex (ILFC), College of Veterinary and Animal Sciences, Udgir and farmer's flock at Village-Valandi in Udgir Tehsil from the period October 2019 to October 2020. About 4-5 $\mathrm{ml}$ of blood was collected from all the animals using aseptic conditions from Jugular vein and was then carried to the laboratory on ice, stored at $4{ }^{\circ} \mathrm{C}$ till DNA isolation was performed. Genomic DNA was isolated using DNA isolation kit (QIAamp DNA Blood Mini Kit) as per manufacturer's instructions. The DNA was quantified using UV spectrophotometer. Sequence specific primers reported by Gowane et al. (2017a) and Gowane et al. (2017b) were utilized to amplify the region of interest. The polymerase chain reaction (PCR) was carried out in a total volume $50 \mu \mathrm{l}$ solution containing $1 \mu$ lemplate DNA, $10 \mathrm{X}$ buffer with $\mathrm{Mgcl}_{2}$ $5 \mu \mathrm{l}, 2.5 \mathrm{Mm}$ dNTPs (100 $\mu \mathrm{M}$ each) $1.0 \mu \mathrm{l}$, forward primer $(20 \mathrm{pmol} / \mu \mathrm{l}) 1.0 \mu \mathrm{l}$, reverse primer $(20 \mathrm{pmol} / \mu \mathrm{l}) 1.0 \mu \mathrm{l}$ and Taq DNA polymerase $1.0 \mu \mathrm{l}$. The denaturation was done at $94^{\circ} \mathrm{C}$, anneling at $60^{\circ} \mathrm{C}$ and extension at $72^{\circ} \mathrm{C}$ for about 35 cycles. PCR products were separated by electrophoresis on $2.5 \%$ agarose gel. Genotyping of samples was carried out at Central Sheep and Wool Research Institute, Avikanagar, Rajasthan.

\section{PCR-Single strand conformation polymorphism (PCR-SSCP)}

PCR- Single strand conformation polymorphism (PCRSSCP) was performed to detect variation in gene. Aliquots of $10 \mu \mathrm{l}$ purified PCR products obtained after gel extraction were mixed with $10 \mu \mathrm{l}$ loading dye, heated for $5 \mathrm{~min}$ at $95^{\circ} \mathrm{C}$ and chilled on ice for $5 \mathrm{~min}$. The samples were separated by an electrophoresis on a $12 \%$ neutral polyacrylamide gel (Acrylamide:Bis-Acrylamide $=29: 1$ ) at 100 volt for 24 hours. The gels were stained with silver staining to identify SSCP patterns. SSCP patterns were determined by visual/manual analysis of bands.

\section{Faecal sample examination}

Faecal samples were collected in aseptic tubes and transferred to the refrigerator to be stored at $4^{\circ} \mathrm{C}$ for further processing. Faecal eggs were counted by Stoll's dilution method (Soulsby, 1982) as per standard protocol. The data on the faecal egg count was recorded and normalised by log transformation as follows:

$$
\text { LFEC }=\log _{e}(F E C+100)
$$

\section{Statistical analysis}

Linear model of least square analysis (Harvey, 1990) was performed to establish the association between different fixed effects and parasitic resistance indicated by least squares mean of FEC (LFEC). Statistical model considered for the present analysis was;

$$
\hat{Y}=\mu+A_{i}+B_{j}+C_{k}+D_{i}+E_{m}+F_{n}+e_{i j k m n}
$$

Where,

$\hat{Y}$ is LFEC, $\mu$ is global mean.

$A_{i}=i^{\text {th }}$ effect of season on LFEC.

$B_{j}=j^{\text {th }}$ effect of sex on LFEC.

$C_{k}=k^{\text {th }}$ effect of age group on LFEC.

$D_{1}=t^{\text {th }}$ effect of farm on LFEC.

$E_{m}=m^{\text {th }}$ effect of birth type on LFEC.

$F_{n}=n^{\text {th }}$ effect of genotype on LFEC.

$\mathrm{e}_{\mathrm{ijk} k \mathrm{mn}}$ is the error NID $\left(0, \sigma^{2} \mathrm{e}\right)$.

\section{RESULTS AND DISCUSSION}

\section{Genotyping of deccani sheep for Ovar-DRB1 locus}

The DNA samples were visualized under UV illuminator and further on gel documentation system. After optimization of PCR thermal cycle conditions a PCR product $301 \mathrm{bp}$ was obtained and confirmed with a 100 bp ladder (Fig 1). On visualization of polyacrylamide gel, fourteen SSCP patterns were obtained and frequency of pattern $D$ was highest while that of pattern $L$ was lowest (Fig 2 and Fig 3). Each pattern displayed variable number of bands in variable arrangements (Table 1). In accordance with the present findings, Bhide and Mikula (2005), studied polymorphism in DRB1 region in Valachian sheep and revealed 25 different SSCP patterns in 400 sheep. Similarly, SSCP patterns ranging from 11 to 31 were reported in different breeds of sheep (Shaobin et al., 2015, Zamani et al., 2016, Gowane et al., 2017a).

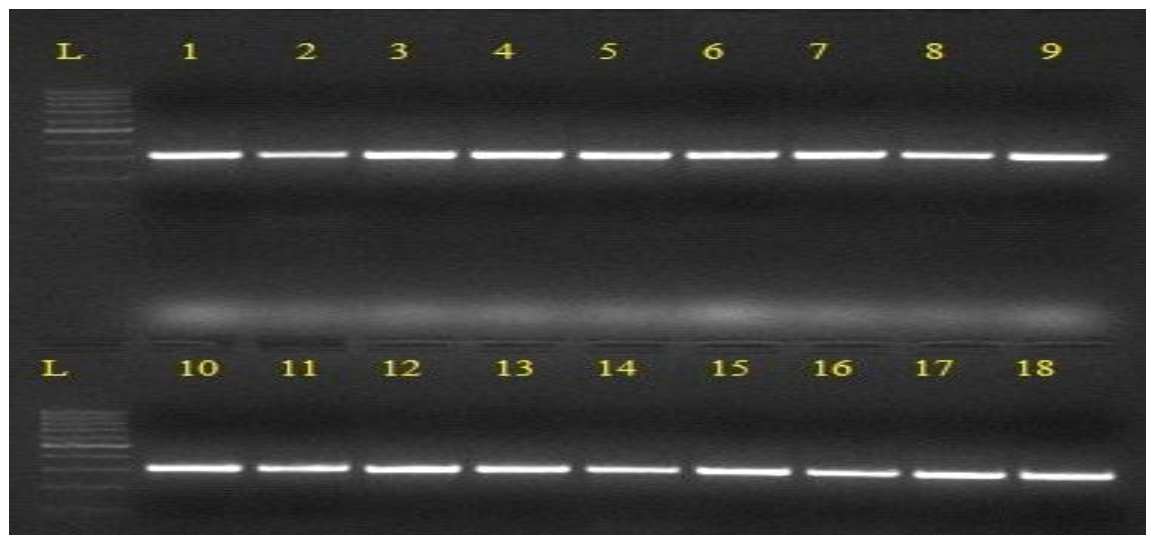

Fig 1: PCR product of 301 bp for Ovar-DRB1 exon 2 gene.

( $L$ for Ladder $100 \mathrm{bp}$; Lane 1 and 2 PCR products). 
Association between the Ovine MHC-DRB1 Gene and its Resistance to Gastrointestinal Parasites in Deccani Sheep Raised in Hot...

\section{Seasonal variations in the faecal egg count (FEC)}

The range of FEC observed was zero to 6600 eggs and maximum FEC was observed for a sheep of SSCP variant $J$

Table 1: Details of band pattern for PCR-SSCP.

\begin{tabular}{lccc}
\hline Pattern & $\begin{array}{c}\text { Numbers of } \\
\text { bands }\end{array}$ & $\begin{array}{c}\text { Number of } \\
\text { observation }\end{array}$ & $\begin{array}{c}\text { Frequency } \\
(\%)\end{array}$ \\
\hline A & 4 & 2 & 4 \\
B & 4 & 2 & 4 \\
C & 3 & 3 & 6 \\
D & 3 & 9 & 18 \\
E & 3 & 2 & 4 \\
F & 3 & 3 & 6 \\
G & 3 & 7 & 14 \\
H & 3 & 8 & 16 \\
I & 3 & 2 & 4 \\
J & 4 & 2 & 4 \\
K & 3 & 2 & 4 \\
L & 3 & 1 & 2 \\
M & 3 & 3 & 6 \\
N & 3 & 4 & 8 \\
\hline
\end{tabular}

Table 2: Mean values of FEC and LFEC in different season.

\begin{tabular}{lcc}
\hline Season & FEC & LFEC $^{* *}$ \\
\hline Monsoon & $916 \pm 157.385$ & $6.54 \pm 0.130^{\mathrm{a}}$ \\
Winter & $96 \pm 11.051$ & $5.25 \pm 0.139^{\mathrm{b}}$ \\
Summer & $76 \pm 10.902$ & $5.14 \pm 0.139^{\mathrm{b}}$
\end{tabular}

(a, b Means with different superscripts in a column differ significantly $\left.{ }^{* *} \mathrm{P}<0.01\right)$. in monsoon season. Factor season was found to have a significant source of variation on FEC as compared to other genetic and non-genetic factors. The mean egg count of parasite in monsoon season was significantly higher followed by winter and least in summer (Table 2). Monsoon is the season that is more favorable for the parasites to develop, survive and infect the animals. Presence of different stages of parasites makes them possible to infect animals, leading to presence of higher load of parasitic eggs in faeces, as evident in our findings. The findings are in accordance with Swarnkar and Singh (2014); Molla and Bandyopadhyay (2016) and Dappawar et al. (2018) in different breeds of sheep. It was inferred that, young animals demonstrated slightly higher FEC than the lambs and low in adult animals in monsoon season. In summer season, FEC was highest in lambs followed by adults and least in young animals. Adult animals displayed a higher FEC in winter season followed by lambs and young (Table 3 ). The results are in accordance with McManus et al. (2009) and Dappawar et al. (2018) were in no significant association was reported between FEC and age of animals.

It was also observed that males displayed a high count of parasitic eggs than females throughout all seasons however; it was statistically non-significant (Table 4). Different hormonal status in sexes affects the immunological responses of sheep to nematodes (Gauly et al., 2006). Thus, it is common to see the males being more prone to parasitic invasion than females. It has also been reported that difference between females and males in parasite susceptibility are probably caused by a difference in

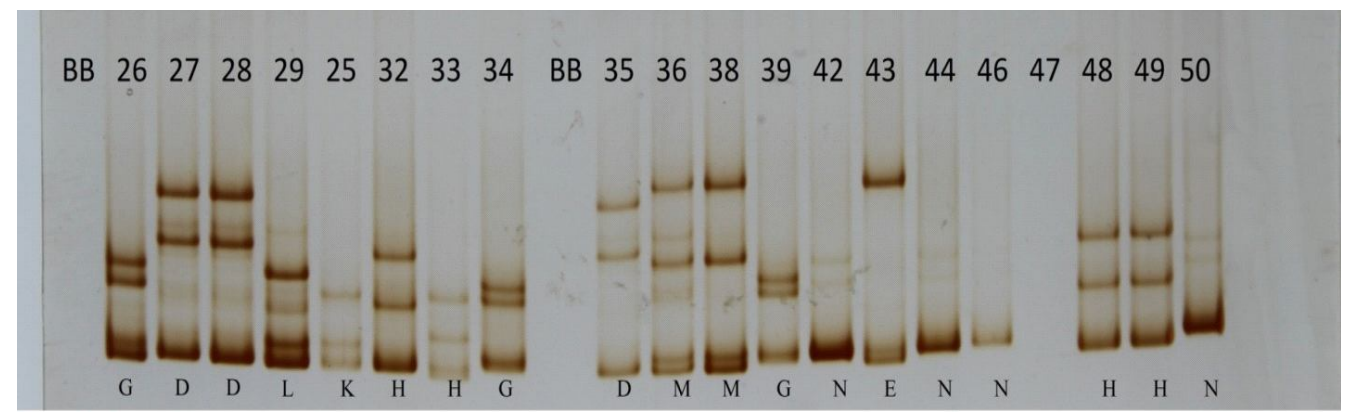

Fig 2: SSCP patterns of PCR product for Ovar-DRB1 exon 2 gene.

(Lane 1 Sample number, BB- Blank; Lane 2 SSCP patterns assigned to variants).

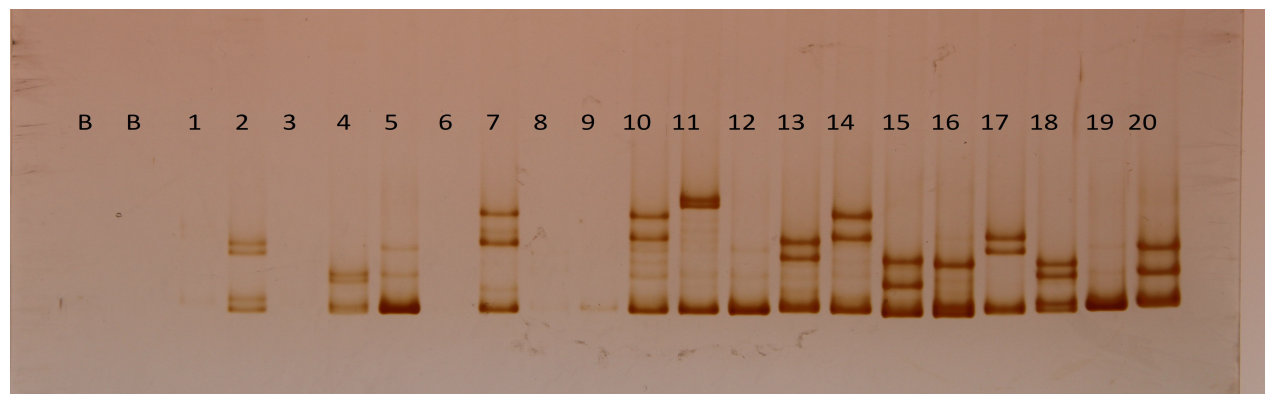

Fig 3: SSCP patterns of PCR product for Ovar-DRB1 exon 2 gene.

(Lane 1 Sample number, B-blank). 
Association between the Ovine MHC-DRB1 Gene and its Resistance to Gastrointestinal Parasites in Deccani Sheep Raised in Hot...

behaviour, morphology and physiological status of sex (Zuk and McKean 1996). Similar results were reported by McManus et al. (2009) and Dappawar et al. (2018).

Further, the animals born as singles/giving birth to singles observed lower FEC during all seasons as compared to the animals born as multiples/giving birth to multiples (Table 5). Romjali et al. (1997) and Haile et al. (2007) explained that the differences in FEC may be contributed to better rearing and nutrition conditions in the singletons in comparison to the multiples. Similar results were reported in Brazilian sheep (McManus et al., 2009). Frequency of fourteen SSCP patterns across different seasons revealed that, pattern $\mathrm{G}, \mathrm{I}$ and $\mathrm{M}$ had higher FEC in monsoon (Table 6). These results are similar to those reported by Sayers et al. (2005) in Texel sheep and Kumari et al. (2020) in Munjal sheep.

\section{Association of FEC with genotype}

FEC ranged from zero to 6600 in the study leading to huge variation in the data. This led to a high standard error associated with FEC. In order to normalize the data, a conversion of FEC to LFEC was done. Linear model of least square analysis was performed to establish the association

Table 3: Mean values of FEC and LFEC for different age groups.

\begin{tabular}{lrrrrrr}
\hline \multirow{2}{*}{ Age group } & \multicolumn{2}{c}{ Monsoon } & \multicolumn{2}{c}{ Winter } & \multicolumn{2}{c}{ Summer } \\
\cline { 2 - 7 } & \multicolumn{1}{c}{ FEC } & LFEC & FEC & LFEC & FEC & LFEC \\
\hline Lamb (0 to 6 months) $\mathrm{n}=13$ & $1130.77 \pm 262.24$ & $6.752 \pm 0.281$ & $84.615 \pm 15.38$ & $5.170 \pm 0.094$ & $84.62 \pm 22.21$ & $5.125 \pm 0.127$ \\
Young (6 months to $1 \mathrm{yr}$ ) $\mathrm{n}=12$ & $1133.33 \pm 250.25$ & $6.777 \pm 0.288$ & $58.333 \pm 24.10$ & $5.111 \pm 0.137$ & $83.333 \pm 19.30$ & $4.986 \pm 0.119$ \\
Adult (above 1 yr) $\mathrm{n}=25$ & $700 \pm 256.12$ & $6.179 \pm 0.187$ & $108.00 \pm 17.24$ & $5.239 \pm 0.095$ & $80.00 \pm 16.33$ & $5.091 \pm 0.093$ \\
\hline
\end{tabular}

( $n=$ no. of animals in each group).

Table 4: Mean values of FEC and LFEC for sex group.

\begin{tabular}{lccccrc}
\hline \multirow{2}{*}{ Sex } & \multicolumn{2}{c}{ Monsoon } & \multicolumn{2}{c}{ Winter } & \multicolumn{2}{c}{ Summer } \\
\cline { 2 - 7 } & FEC & LFEC & FEC & LFEC & \multicolumn{1}{c}{ FEC } & LFEC \\
\hline Male $\mathrm{n}=5$ & $960 \pm 380.263$ & $6.485 \pm 0.577$ & $140 \pm 40$ & $5.403 \pm 0.214$ & $80 \pm 37.416$ & $5.102 \pm 0.215$ \\
Female $\mathrm{n}=45$ & $911.111 \pm 170.834$ & $6.470 \pm 0.146$ & $91.111 \pm 11.380$ & $5.166 \pm 0.064$ & $75.556 \pm 11.527$ & $5.071 \pm 0.066$ \\
\hline
\end{tabular}

( $n=$ no. of animals in each group).

Table 5: Mean values of FEC and LFEC for Birth type.

\begin{tabular}{lrrrrrr}
\hline \multirow{2}{*}{ Birth type } & \multicolumn{2}{c}{ Monsoon } & \multicolumn{2}{c}{ Winter } & \multicolumn{2}{c}{ Summer } \\
\cline { 2 - 7 } & \multicolumn{1}{c}{ FEC } & LFEC & FEC & \multicolumn{1}{c}{ LFEC } & \multicolumn{1}{c}{ FEC } & LFEC \\
\hline Single $\mathrm{n}=47$ & $914.634 \pm 186.415$ & $6.442 \pm 0.157$ & $90.243 \pm 11.998$ & $5.160 \pm 0.068$ & $68.292 \pm 11.282$ & $5.036 \pm 0.067$ \\
Multiple $\mathrm{n}=3$ & $950 \pm 287.228$ & $6.729 \pm 0.137$ & $133.333 \pm 33.333$ & $5.385 \pm 0.175$ & $150 \pm 34.156$ & $5.453 \pm 0.182$ \\
\hline
\end{tabular}

( $n=$ no. of animals in each group).

Table 6: Mean values of FEC and LFEC for SSCP patterns.

\begin{tabular}{lcccccc}
\hline Patterns & \multicolumn{2}{c}{ Monsoon } & \multicolumn{2}{c}{ Winter } & \multicolumn{2}{c}{ Summer } \\
\cline { 2 - 7 } & FEC & LFEC & FEC & LFEC & FEC & LFEC \\
\hline A & $50 \pm 50.001$ & $4.952 \pm 0.347$ & $50 \pm 50$ & $4.951 \pm 0.346$ & $150 \pm 50.001$ & $5.501 \pm 0.202$ \\
B & $850 \pm 550$ & $6.652 \pm 0.661$ & $50 \pm 50$ & $4.951 \pm 0.346$ & $150 \pm 50.001$ & $5.501 \pm 0.202$ \\
C & $600 \pm 251.661$ & $6.432 \pm 0.335$ & $100 \pm 57.735$ & $5.202 \pm 0.320$ & $33.333 \pm 33.335$ & $4.836 \pm 0.231$ \\
D & $800 \pm 192.930$ & $6.602 \pm 0.231$ & $77.778 \pm 27.778$ & $5.080 \pm 0.159$ & $66.667 \pm 23.570$ & $5.035 \pm 0.142$ \\
E & $750 \pm 150$ & $6.729 \pm 0.178$ & $50 \pm 50$ & $4.951 \pm 0.346$ & $100 \pm 100$ & $5.154 \pm 0.549$ \\
F & $500 \pm 450.924$ & $5.739 \pm 0.812$ & $66.667 \pm 33.334$ & $5.067 \pm 0.231$ & $100 \pm 57.735$ & $5.202 \pm 0.320$ \\
G & $1128.571 \pm 434.639$ & $6.694 \pm 0.420$ & $100 \pm 37.796$ & $5.175 \pm 0.208$ & $71.428 \pm 28.571$ & $5.059 \pm 0.169$ \\
H & $700 \pm 225.198$ & $6.407 \pm 0.286$ & $112.5 \pm 22.658$ & $5.313 \pm 0.120$ & $50 \pm 26.726$ & $4.915 \pm 0.157$ \\
I & $1150 \pm 850$ & $6.821 \pm 0.829$ & $150 \pm 50$ & $5.501 \pm 0.202$ & $100 \pm 100$ & $5.154 \pm 0.549$ \\
J & $4000 \pm 2600$ & $8.062 \pm 0.748$ & $150 \pm 50$ & $5.501 \pm 0.202$ & $150 \pm 50.001$ & $5.501 \pm 0.202$ \\
K & $300 \pm 100$ & $5.959 \pm 0.255$ & $50 \pm 50$ & $4.951 \pm 0.346$ & $50 \pm 50.001$ & $4.951 \pm 0.346$ \\
L & $0 \pm 0$ & $4.605 \pm 0$ & $200 \pm 0$ & $5.703 \pm 0$ & $200 \pm 0$ & $5.703 \pm 0$ \\
M & $1200 \pm 850.490$ & $6.738 \pm 0.638$ & $166.667 \pm 33.334$ & $5.568 \pm 0.135$ & $0 \pm 0$ & $4.605 \pm 0$ \\
$\mathrm{~N}$ & $1000 \pm 348.807$ & $6.595 \pm 0.667$ & $75 \pm 47.871$ & $5.053 \pm 0.271$ & $75 \pm 25$ & $5.125 \pm 0.173$ \\
\hline
\end{tabular}


Table 7: LSM values of genotypes SSCP pattern.

\begin{tabular}{lc}
\hline SSCP pattern & LS means \& SE for FEC ${ }^{* *}$ \\
\hline A & $5.296 \pm 0.312$ \\
B & $5.864 \pm 0.312$ \\
C & $5.460 \pm 0.262$ \\
D & $5.601 \pm 0.162$ \\
E & $5.520 \pm 0.319$ \\
F & $5.255 \pm 0.255$ \\
G & $5.804 \pm 0.177$ \\
H & $5.696 \pm 0.173$ \\
I & $5.598 \pm 0.339$ \\
J & $6.516 \pm 0.309$ \\
K & $5.449 \pm 0.312$ \\
L & $5.501 \pm 0.416$ \\
M & $5.824 \pm 0.293$ \\
N & $5.658 \pm 0.226$ \\
\hline (LFEC $=$ Season ${ }^{*}$ sex $^{*}$ age ${ }^{*}$ farm ${ }^{*}$ birth type* tenotype; $^{* *}$ Highly \\
significnat).
\end{tabular}

between genotype of exon 2 Ovar-DRB1 gene and parasitic resistance indicated by LFEC. The coefficient of determination $\left(R^{2}\right.$ value) for model considered in the study was $54 \%$ $(P<0.01)$. Least square means of LFEC for genotype $\mathrm{J}$ was highest $(6.516 \pm 0.309)$ followed by genotype $B(5.864 \pm 0.312)$ and genotype $F(5.255 \pm 0.255)$. It was inferred from the study that the genotype $\mathrm{J}$ may be associated with higher LFEC $(P<0.01)$ while genotype $\mathrm{F}$ may be associated with reduced LFEC. Therefore, the animals with genotype $F$ for exon 2 Ovar-DRB1 could be said to be resistant to parasitic invasion as attributed to Ovar-Mhc (Table 7).

\section{CONCLUSION}

Molecular characterization of Ovar-DRB1 exon 2 revealed fourteen genotypes patterns represented by PCR-SSCP. The study suggested possible association of genotype ' $F$ ' and genotype ' $\mathrm{J}$ ' with parasitic resistance and susceptibility in Deccani sheep. Findings revealed that DRB1 gene is associated with immune response to parasitic invasion and selection for genotype associated with Ovar-Mhc-DRB1 gene could improve the parasitic resistance in Deccani sheep. However, parasitic resistance is a lowly heritable trait affected by many environmental and non genetic factors therefore large scale study on a considerable number of samples is needed for better confirmation.

\section{ACKNOWLEDGMENT}

The authors are grateful to Director, ICAR-CSWRI, Avikanagar, Rajasthan for providing necessary facility to carry out this research. The valuable help of Associate Dean, College of Veterinary and Animal Sciences, Udgir Dist- Latur and Deputy Director Research, Cattle Breeding Farm, College of Veterinary and Animal Sciences, Udgir Dist- Latur is also duly acknowledged.

Conflict of interest: None.

\section{REFERENCES}

Ashrafi, F., Hashemi, A., Mardani, K. and Darvishzadeh, R. (2014). Study on genetic variability in Mhc-DRB1 second exon in makuie sheep breed population. Genetica. 46: 269275. DOI: $10.2298 / G E N S R 1401269$ A.

Bhide, M.R. and Mikula, I. (2005): Asymmetric PCR-SSCP: a Useful Tool for Detection of OLA-DRB1 (Mhc class II) Gene Polymorphism in Slovak Improved Valachian Sheep. Acta Veterinaria Brno. 74: 275-278.

Brown, J.H., Jardetzky, T.S., Gorga, J.C. and Stern, L.J. (1993). Three-dimensional structure of the human class II histocompatibility antigen HLA-DR1. Nature. 364: 33-39.

Charon, K.M., Moskwa, B., Rutkowski, R., Gruszczynskal, J. and Swiderek, W. (2002). Microsatellite polymorphism in DRB1 gene (Mhc class II) and its relation to nematode faecal egg count in Polish Heath Sheep. Journal of Animal and Feed Science. 11: 47-58.

Dappawar, M.K., Khillare, B.S., Narladkar, B.W. and Bhangale, G.N. (2018). Prevalence of gastrointestinal parasites in small ruminants in Udgir area of Marathwada. Journal of Entomology and Zoology Studies. 6(4): 672-676.

Gauly, M., Schackert, M., Hoffmann, B. and Erhardt, G. (2006). Influence of sex on the resistance of sheep lambs to an experimental Haemonchus contortus infection. Deut Tierarztl Woch. 113: 178-181.

Gowane, G.R., Najif Akram, L.L., Prince, L., Prakash, V. and Kumar, A. (2017a). Ovar-Mhc Polymorphism in Malpura and Avikalin Sheep vaccinated for Peste des Petits Ruminants (PPR) Virus. Animal Biotechnology. 28(4): 306-314.

Gowane, G.R., Najif Akram, L.L., Prince, L., Ved Prakash and Arun Kumar. (2017b). Genetic appraisal of serological response post vaccination against enterotoxaemia (ET) in Malpura and Avikalin sheep. Tropical Animal Health Production. 49: 867-873.

Haile, A., Tibbo, M., Baker, R.L. and Rege, J.E.O. (2007). Effects of nongenetic factors on responses to gastro-intestinal nematode infections in Ethiopian sheep. Tropical Animal Health Production. 39(6): 411-417

Harvey, W.R. (1990). User's Guide for LSMLMW, MIXMDL, PC-2I Version. Columbus:

Kumar, R.R., Yadav, C.L., Garg, R., Banerjee, P.S. and Vatsya, S. (2008). Prevalence of gastro-intestinal nematodes in sheep and goat in some parts of north-west India. Indian Journal of Animal Science. 78(11): 1244-1246.

Kumari, A., Kumar, A., Tomar, P., Baro, D., Grewal, S. and Sangwan, M.L. (2020). Mhc-DRB1 exon 2 polymorphism and its association with faecal egg count of Haemonchus contortus in Munjal sheep. Indian Journal of Experimental Biology. 58: 365-369.

McManus, C., Helder, L., Samuel, R.P., Amaury, A.D.O., Hymerson, C.A. and Cristiano, B.D.M. (2009). Genetic factors of sheep affecting gastrointestinal parasite infections in the Distrito Federal, Brazil. Veterinary Parasitology. 166: 308-313.

Molla, S.H. and Bandyopadhyay, P.K. (2016). Prevalence of gastrointestinal parasites in economically important Bonpala sheep in India. IOSR-Journal of Agriculture and Veterinary Science. 9(1): 87-93. 
Outteridge, P.M. andersson, L., Douch, P.G.C. and Green, R.S. (1996). The PCR typing of Mhc-DRB genes in the sheep using primers for an intronic microsatellite: Application to nematode parasite resistance. Immunology and Cell Biology. 74: 330-336.

Paterson, S., Wilson, K. and Pemberton, J.M. (1998). Major histocompatibility complex variation associted with juvenile survival and prasite resistance in a large ungulate population (Ovis aries L.). Proceedings of the National Academy of Sciences. U.S.A. 95: 3714-3719. DOI: 10.1073/pnas.95.7.3714.

Rangnekar, D.V. (2006). Livestock in the livelihoods of the underprivileged communities in India: A Review. ILRI (aka ILCA and ILRAD).

Romjali, E., Pandey, V.S., Gatenby, R.M., Doloksaribu, M., Sakul, H., Wilson, A. and Verhulst, A. (1997). Genetic resistance of different genotypes of sheep to natural infections with gastro-intestinal nematodes. Animal Science. 64: 97-104

Saddiqi, H.A., Abdul, J., Muhammad, S., Zafar I., Ghulam, M., Mahrun, N. and Aasif, S. (2011). Small ruminant resistance against gastrointestinal nematodes: A case of Haemonchus contortus. Parasitology Research. 109: 1483-1500.

Shaobin, L., Yuzhu, L., Jiang, H., Jiqing, W., Xiu. L. and Wei. Y. (2015). Variation of $D R B 1$ Gene in Tibetan Sheep. Journal of Life Sciences. 9: 255-261.
Soulsby, E.J.L. (1982). Helminths, arthropods and protozoa of domesticated animals. $7^{\text {th }}$ edition ELBS and Bailliere Tindall, London. pp 765-768.

Swarnkar, C.P. and Singh, D. (2014). Influence of annual rainfall on epidemiology of gastrointestinal parasites in sheep flocks of Rajasthan. Indian Journal of Animal Sciences. 84(11): 1171-1176.

Sayers, G., Good, B., Hanrahan, J.P., Ryan, M., Angles, J.M. and Sweeney, T. (2005). Major histocompatibility complex DRB1 gene: Its role in nematode resistance in Suffolk and Texel sheep breeds. Prasitology. 131: 403-409.

Valilou, R.H., Rafat, S.A., Notter, D.R., Shojda, D., Moghaddam, G. and Nematollahi, A. (2015). Fecal egg counts for gastrointestinal nematodes are associated with a polymorphism in the Mhc-DRB1 gene in the Iranian Ghezel sheep breed. Frontiers Genetics. 6: 105.

Zamani, P., Hosein S. D., Abbas D. and Alireza A. (2016). Ovine $D R B 1$ polymorphism and its associations with body weight, milk contents and immunological parameters. Annuals of Animal Science. 16(2): 425-438.

Zuk, M. and McKean, K.A. (1996). Sex differences in parasite infections: patterns and processes. International Journal of Parasitology. 26: 1009-1023. 